\title{
Regulation of Foreigner Stay Permit as Director of Limited Liability Company and Investor in Foreign Investment
}

\author{
Tri Sutjiati* and Ida Ayu Sadnyini \\ Undiknas Pasca Sarjana, Denpasar, Bali \\ *Email: titiek.sureau@gmail.com
}

How to cite (in APA style):
Sutjiati, T., Sadnyini, I, A. (2021). Regulation of Foreigner Stay Permit as Director of Limited Liability Company and
$\begin{aligned} & \text { Investor in Foreign Investment. Jurnal Hukum Prasada, 8(2), 89-100. doi: https://doi.org/10.22225/ } \\ & \text { jhp.8.2.2021.89-100 }\end{aligned}$

\begin{abstract}
Based to Article 10 Paragraph (1) on Regulation Ministry of Manpower Number 10 Year 2018 Concerning Procedure of Employ Foreign Worker says that employer of the foreign worker is not required to possess any EPP (working permit) to employ foreign workers who are shareholders with the position of the board of directors or board of commissioners, as it is stated before on Article 10 Paragraph (1) Presidential Decree No. 20 Year 2018 Concerning Foreign Worker. Nevertheless, the facility for investors to possess stay permits in Indonesia which is mentioned in Article 22 Paragraph (3), Regulation of Ministry of Justice and Human Rights Number 51 Year 2016 Concerning Change of Regulation Number 24 Year 2016 Concerning Technical Procedures for Application and Issuance of Visit Visas and Limited Stay Visas, says that the investor prohibited working. This study aims to investigate the procedure and the regulations that govern temporary stay permits of directors and foreign investors in Indonesia. The method used in this study is normative legal research and meanwhile, statute approach and conceptual approach are used as the approach of this study. The results of this study showed that 1) higher norms govern action, as to create lower norms, governs realization of action. Presidential Decree has a higher position in the hierarchy from Ministry Regulations. 2) ideal framework of statutory regulations shall consist of a balance portion of justice, legal certainty and finality.
\end{abstract}

Keywords: director; foreigner stay permit; investor; regulation

\section{INTRODUCTION}

Indonesia as a developing country needs investment to be able to turn the pace of development so that it can be appreciated by the wider and remote communities of Indonesia. The need for large funds for development and growth of the nation's economy does not only come from domestic sources, but also comes from foreign sources of funding. Funding from abroad is also known as foreign investment. The motive of a company to invest in a country is to make a profit. The government's need of foreign investment as a source of national development funds requires hard work by creating a conducive investment climate. Several important elements to create a conducive investment climate, the government needs adequate infrastructure, security, social and political stability and law enforcement. Law enforcement should be balance and consist of three elements, namely: legal certainty, justice and benefit (Kairupan, 2013:4).

The purpose of Law Number 25 Year 2007 concerning Investment (hereinafter called as Investment Law) is to be able to compete and side with the national interest. Perception and understanding of investment must provide a strong concept to avoid negative perceptions of investment, especially foreign investment. The Investment Law not only provides basic rules for facilitating licensing in Indonesia, but also provides several facilities 
for investors. One of the facilities for foreign investors is in article 23 paragraph (1) which says: to ease of service and/or licensing for immigration facilities as referred to in Article 21 letter $b$ can be granted for:

Investments that require foreign workers to realize investment;

Investments requiring temporary foreign workers in the framework of repairing machines, other production aids and after-sales services;

Prospective investors who will conduct an investment exploration.

Article 23 paragraph (2) states that the ease of service and/or licensing for immigration facilities provided to investment as referred to paragraph (1) letter a and letter $b$, is given after the investor receives a recommendation from the Investment Coordinating Board (hereinafter called as ICB). Article 23 paragraph (3) explains that:

Granting a limited stay permit for foreign investors for 2 (two) years;

The granting of a change from the status of a limited stay permit for an investor to a permanent residence permit can be done after living in Indonesia for 2 (two) consecutive years.

Article 23 paragraph (4) of the Investment Law states that:

The granting of limited stay permits for foreign investors as referred to in paragraph (3) letters $a$ and $b$ is carried out by the Directorate General of Immigration on the basis of a recommendation from the ICB.

Chapter VII Article 47 Regulation of the Head of ICB Number 5 Year 2019 Concerning Change of Regulation Number 6 Year 2018 Concerning of Guidelines and Procedures for Investment Licensing and Facilities (hereinafter referred to as Regulation of the Head of ICB Concerning Guidelines and Procedures for Licensing and Investment Facilities) describes the provision of recommendations for limited stay visa facilities, recommendations for granting change of status from visiting residence permit to limited stay permit and granting of recommendation for change of status from limited stay permit to permanent residence permit. Article 48 of Regulation of the Head of ICB Concerning Guidelines and Procedures for Licensing and Investment Facilities, stipulates that the provision of recommendations is given to foreign investors which is a requirement for obtaining approval for a limited stay visa. This recommendation facility is given to foreign investors who own minimum shares per person or per investor of IDR 1,000,000,000 and occupy a position of director or commissioner, as well as an investor having a minimum share of IDR $1,250,000,000$ without occupying any position in the company, a limited stay visa recommendation facility can be granted. ICB provides a letter of recommendation, which is the basis for applying a limited stay permit requires by Directorate General of Immigration, states:

Limited stay visa for 1 to 2 years, a working status, for position as Director and foreign investor.

Limited stay visa for 1 to 2 years, not a working status, for position as Commissioner and foreign investor.

Article 10 paragraph (1) Regulation of the Minister of Manpower and Energy of Mineral Resources Number 10 Year 2018 Concerning Procedures for the Use of Foreign Workers (hereinafter referred to as Regulation Minister of Manpower and Energy of Mineral Resources Concerning Procedures for the Use of Foreign Workers) states that foreign workers are not required to have Expatriate Placement Plan or Working Permit (hereinafter referred to EPP), who are:

Shareholders who serve as members of the board of directors or 
commissioners of foreign workers;

Diplomatic and consular employees at representative offices of foreign countries or;

Foreign workers in the type of work required by the government.

Based on the Regulation of the Minister of Manpower and Energy of Mineral Resources Concerning Procedures for the Use of Foreign Workers, directors and commissioners who are also foreign shareholders (foreign investors) of a company shall no longer need a EPP (Expatriate Placement Plan) which is a work permit as a basic requirement to be able to work in Indonesia. PT. Studio Corner Bali is a limited liability company in a form of foreign investment with $100 \%$ foreign investment. The board of directors and commissioners use the recommendation facility and limited stay permit as foreign investors with 2 years validity. Recommendation letter from ICB received with working status for investor with position as director and non-working status for investor with position as commissioner. However, on the process of stay permit in Directorate General Immigration and Embassy of Indonesia in Singapore, visa received code are index code visa number C314 and was written "prohibited for working" both for investor with position as director, also for investor with position as commissioner. This is contrary of what being written in the recommendation letter from ICB.

Minister of Manpower and Energy of Mineral Resources authorize to issue a EPP for foreigner. Regulation Minister of Manpower and Energy of Mineral Resources Concerning Procedures for the Use of Foreign Workers confirms that the existence of EPP is no longer required for foreign investors in a limited liability company that has positions as directors and commissioners. However, what is written on the stay permit, foreign investors who also hold positions on the board of directors or directors of a company, are eventually granted a limited stay permit for 1 or 2 years in Indonesia with a status of prohibited for working (shall not work).

After being examined, it seems that there is a conflict of norms between Article 22 paragraph (3) letter a of the Regulation of Ministry of Justice and Human Rights Number 51 Year 2016 Concerning Change of Regulation Number 24 Year 2016 Concerning Technical Procedures for Application and Issuance of Visit Visas and Limited Stay Visas (hereinafter referred to as Regulation of Ministry of Justice and Human Rights Concerning Technical Procedures for Application and Issuance of Visit Visas and Limited Stay Visas) and Article 10 paragraph (1) of the Regulation Minister of Manpower and Energy of Mineral Resources Concerning Procedures for the Use of Foreign Workers. The Regulation of Ministry of Law and Human Rights issues a stay permit for investors who are also company directors, with the status of not working, the Minister of Manpower and Energy of Mineral Resources provides facilities for an investor and company directors with certain amount of shares, to no longer apply a EPP.

The study about the legal aspect of the regulation of foreigner stay permits has been conducted previously by some researchers. Bunawan (2017) in his study about Foreign Investment in Indonesia the Legal Aspects under the New Indonesian Investment Law showed that Indonesia stipulated The Indonesian Investment Law. It provides the easiness, simplicity and supportive facilities to attract investors both domestic and overseas. Thus, the principle of the same treatment both for domestic and foreign investors accommodate the need for openness, a transparent and conducive business environment in Indonesia, not only for the sake of the people of Indonesia, even for the global community in the world. Another similar study also conducted by Rusdiko et al. (2019) that examined Legal Certainty of Guarantor for the Existence of Foreign Investors in Indonesia, 
revealed that there has been a vacuum of norms regarding guarantors for certain foreign investors in obtaining guarantors that guarantee their existence in the Territory of Indonesia. This causes legal uncertainty for the guarantor and the investor in obtaining a residence permit. Therefore it is necessary to deregulate existing laws and regulations so that the guarantor and investors get legal certainty and protection while they are in the territory of Indonesia. In addition, a study conducted by Taduri (2021) entitled The Legal Certainty and Prot ection of Foreign Investment Againsts Investment Practices in Indonesia, showed that In order to create legal certainty for foreign investors, it is necessary to conduct a review of the investment law, carry out equity restriction and reform the judicial system.

Based on the background and the previous studies above, it seems that the regulation of foreigner to stay permit is necessary to be examined. Therefore, this study aims to investigate the procedure and the regulations that govern temporary stay permits of directors and foreign investors in Indonesia.

\section{LITERATURE REVIEW}

\section{Theory Gradual.}

The entire statutory system is tiered based on a juridical order. The statutory system is sequential like a pyramid, starting from the abstract, such as the basic norm or constitution (grundnorm) so that it takes concrete forms such as laws, government regulations, and others. One of student of Hans Kelsen, Hans Nawiasky, said that legal norms in a country are always layered and tiered. Lower norms are applicable and based from higher norms, until it reached up a higher norm called grundnorm (Indrati, 2007:44). The interpretation of Theory Hans Kelsen showed that all laws are in one source of the constitution as its basic norm. Based on Regulation No. 12 Year 2011 Concerning Formation of Laws and Regulations (hereinafter referred to as Regulation Concerning Formation of Laws and Regulations), the logic of legal studies are the rules that must be considered in measuring the consistency of a grundnorm, which are as follows:

Derogation rules are every rule of law comes from a higher rule.

Recognition rules, namely for every applicable legal rule there must be acknowledgment from the authority to enforce the rule, as well as recognition from the party to whom the legal rule will be applied.

Rule of non-contradiction, there should be no contradiction between legal rules and other legal rules, so that between one legal norm and another must be harmonious, synchronous and integrated.

Derivative rule is a law rule at a lower level which is part of a higher-level legal rule and based on the principle of practical deduction.

The rule of the system, namely the lower level legal system is a sub-system of higher legal regulations, so that all applicable legal rules constitute a system as a whole.

The rule of generalization is a higher legal rule is a generalization of a lower legal rule, and vice versa.

The reduction rule which is a lower law rule is a reduction from a higher rule.

The rule of the coverage category, namely the rule of law must still belong to or be included in a higher class of rules and not originate from the rules of another group (Fuady, 2013:142-143).

Based on principles of law above, a process of delegating grundnorms by the constitution into norms which will be regulated in tiered as follow:

Concretized by Central of Legislative.

Concretized by Central of Administrative.

Concretized by Central of Justice.

Concretized by habits in the society. 
Concretized by privates transactions (Fuady, 2013:140).

Hans Kelsen's theory defines that all laws are in one source of the constitution as its basic norm. Regulation Concerning Formation of Laws and Regulations, types and hierarchies in Indonesia are as follows:

Constitution of the Republic of Indonesia of 1945;

People's Consultative Council Decree;

Law/Government Regulation In Lieu of Law;

Government Regulation;

Presidential Regulation;

Province Regulation; and

Regency/Municipality Regulation.

If there are two conflicting legal rules, it is certain that one or both of them are outside the existing system, so that such legal rules are considered invalid. The rule of law can authorize a special organ to declare a norm null and void, that is, to cancel a norm retroactively so that the legal effect since the norm is stipulated is abolished (Asshiddiqie \& Safa'at, 2018:130). Hans Kelsen tends to use legal principles, one of which is specific law, overriding general laws (lex specialis derogat legi generalis) and newer laws override older laws (lex posterior derogat legi priori) (Fuady, 2013:121).

\section{Theory of Legal Philosophy.}

$\mathrm{Ph}$. A A. Housing analyses the development of civil law, namely from the uncertainty of unwritten law, then written legal rules and codification are born (Syaifuddin, 2012:50). Legal certainty in the form of written legal rules provides guarantees for legal subjects and also provides a description of the legal consequences that can arise if the legal subject violates these legal rules. $M$. Isnaeni explained that legal instruments that pay attention to consistency will be able to give birth to the meaning of legal certainty as expected by a wider audience. On the other hand, if there is no flow of consistency within these statutory regulations, meaning that the image itself is uncertain, then it is difficult to expect legal certainty from the womb of such rules (Syaifuddin, 2012).

Legal certainty, according to Gustav Radbruch, shows assurance that the law actually functions as a rule that is obeyed and is a legal operational framework (Rahardjo, 2013:118). Gustav Radbruch in his theory gives 3 aspects in overcoming the dualism between sein and sollen, which are:

Justice is an aspect that provides the value of justice as a material for the content of rules in the form of law and legal rules are a form that must protect the value of justice. The law as the bearer of justice must be a measure of the fairness and unfairness of the legal order. The value of justice is also the basis of law. Therefore, justice has constitutive and normative characteristics for the law itself. Normative because it functions as a transcendental prerequisite that underlies every positive law and becomes the moral basis for the law so that it also becomes the benchmark for a positive legal system. The aspect of justice shows equal rights before the law.

Legal certainty which consist of guarantee that the law containing norms of promoting goodness actually functions as a rule that is obeyed. Legal certainty is an operational framework.

Finality is a goal of fairness. The finality aspects are determined by content of law and are the ideal framework of law. Finality contains an element of revitalization because the purpose of justice is the content of law to foster the value of goodness for humans, more as an ethical value in law (Rahardjo, 2013).

Three legal principles give Radbruch confidence that justice for individuals is the foundation as the embodiment of justice in law. The three principles must be in an orderly position to avoid arbitrariness. However, if there is a conflict between justice and the rule of law so that it is truly unfair, then on the basis of justice, that foundation must be released. Certainty is used as a supporting factor and determines to maintain the continuity of the 
individual concerned and ensure their safety. According to Radbruch if legal certainty is discussed on the basis of the implementing regulations (geltung des positive rechts) then it will enter into the realm of behavioural action, human beings and other factors that can influence how positive law is run (Ali, 2009).

\section{METHOD}

The method used in this study is normative legal research. Moreover, a statute approach and a conceptual approach are the approaches used in this study. Primary legal materials, secondary legal materials are the type of data of this study. Primary legal materials, including the 1945 Constitution of the Republic of Indonesia, the Investment Law, the Immigration Law, the Limited Liability Company Law, the Regulation of the Minister of Manpower and Energy and Mineral Resources, the Regulation of the Minister of Justice and Human Rights and Regulation of the Head of the Investment Coordinating Board. Secondary legal materials include legal materials that are closely related to primary legal materials so that they can assist writers in analysing and providing explanations for primary legal materials, in the form of law books on legal theories; literature books on investment law, immigration and limited liability companies. In addition, the legal material of this study is in the form of articles related to this study through several legal media on the internet, such as hukumonline.com. In this study, the technique used in collecting the data is a documentary study obtained from several foreign investment companies in Bali, one of which is PT. Studio Corner Bali, a foreign investment company in the form of a limited liability company domiciled in Buleleng Regency. Furthermore, in analyzing the data, there are some steps to be done, they are: a) description, namely by starting to study the explanation and meaning of several laws and regulations and legal books related to the problems in this thesis research proposal. b) Interpretation is an explanation that produces an understanding of the science of law towards existing norms. Horizontal norm conflict between 2 laws and regulations, in this case, is the Ministry of Law and Human Rights Regulation with the Minister of Manpower and Energy and Mineral Resources, using the lex specialist derogate legi generalist principle, namely more specific rules then setting aside general laws and regulations, and lex posterior derogate legi priori, namely the latest legislation which then overrides the previous legislation. c) Argumentation is an understanding of the law that produces legal arguments that have reasons based on legal reasoning.

\section{DISCUSSION}

The procedure for applying for a temporary residence permit for an investor who is also a director of the company.

Investment Law explains that a temporary residence permit is granted by prior recommendation from ICB and carried out by Immigration. This is stated in Article 48 of Regulation Head of ICB Concerning Guidelines and Procedures for Licensing and Investment Facilities, and ICB recommendation criteria for foreign investors who wish to apply for a temporary residence permit in Indonesia. Based on principle of delegation from Article 23 Investment Law, can be found on Article 10 Presidential Regulation Number 20 Year 2018 Concerning Utilization of Foreign Workers (hereinafter called as Presidential Regulation Concerning Utilization of Foreign Workers), which mentions that EPP is not necessarily need for an investor with position as members of the Board of Directors and members of the Board of Commissioners. The Ministry of Manpower which has the authority to issue a work permit for a foreign worker confirmed on Article 10 Paragraph 1 Regulation Minister of Manpower and Energy of Mineral Resources Concerning Procedures for the Use of Foreign Workers that employer of foreign workers is not necessarily posses a EPP includes members of the board of directors or members of the board of commissioners with share ownership in accordance with the provisions of laws and regulations. Article 22 Paragraph 3 Regulation of Ministry of Justice and Human Rights Number 51 Year 2016 Concerning Change of Regulation Number 24 Year 2016 Concerning Technical Procedures for Application and Issuance of Visit Visas and Limited Stay Visas (hereinafter called as Regulation of Ministry of Justice and Human Rights 
Concerning Technical Procedures for Application and Issuance of Visit Visas and Limited Stay Visas) mentions that limited stay visa prohibited for work includes a foreign investor. This is contrary to the Regulation Minister of Manpower and Energy of Mineral Resources Concerning Procedures for the Use of Foreign Workers.

Article 22 Paragraph 3 Regulation of Ministry of Justice and Human Rights Concerning Technical Procedures for Application and Issuance of Visit Visas and Limited Stay Visas mentions that limited stay visa is not for work, includes: foreign investor. The application for a limited stay visa is approved, the Immigration Officer appointed to the Representative of the Republic of Indonesia abroad provide a limited stay visa (vitas) to the passport of the foreign citizen. The process continues after the foreign citizen enters the Indonesian Territory, guarantor or person in charge for the foreigner, must submit an application to grant a limited stay permit (ITAS) no later than 30 (thirty) days from the date the entry sign is issued. Applications for granting residence/stay permits are submitted to the immigration office, whose authority includes the domicile address of the investor. The application is submitted based on Regulation of Ministry of Justice and Human Rights Number 27 Year 2014 Concerning Technical Procedures for Granting, Extension, Refusal, Cancellation and Expiration of Visiting Stay Permits, Limited Stay Permits, and Permanent Stay Permits and Exemptions from Obligations to Have a Stay Permit by attaching conditions as follow:

Company Establishment Deed contains capital ownership and / or shares of foreigners which are invested in Indonesia. letter.

Investment approval letter from the government institution who is in charge of the

Permanent Business Licence.

Effective Business Licence or NIB.

Company Registration.

Company Registration Tax Number.

ICB Recommendation is given based on Regulation of the Head of ICB Concerning Guidelines and Procedures for Licensing and Investment Facilities. Article 48 confirms that recommendation for limited stay visa facility, recommendation for change of status from visiting residence permit to limited stay permit and recommendation for change from status from limited stay permit to permanent residence permit, are given if foreign investors (investors) who have shares of at least Rp. 1,000,000,000 per person or per investor and occupies a position of director or commissioner, or investors owning shares of at least Rp. $1,250,000,000$ without holding any position in the company.

Based on Law Principle Lex Spesialis Derogate Legi Generalis that rule of law on specific legal rules is overriding general legal rules. The granting of permits in the field of manpower for foreign citizens is an authority of Regulation Minister of Manpower and Energy of Mineral Resources is not an authority of Regulation of Ministry of Justice and Human Rights. As well as Regulation of Ministry of Justice and Human Rights was made in year 2016 and Regulation Minister of Manpower and Energy of Mineral Resources was made in 2018. Based on law principle, lex posteriori derogat legi priori, the new rules should override the old rules.

The implementation of temporary residence permit arrangements for foreign investors and limited liability company directors in the laws and regulations relating to residence permits for foreigners.

The laws and regulations which are the basis for implementing the temporary residence permit arrangement for foreign investors consist of:

Article 48 Regulation Head of ICB Concerning Guidelines and Procedures for Licensing and Investment Facilities;

Article 22 Paragraph (2) and (3) Regulation of Ministry of Justice and Human Rights Concerning Technical Procedures for Application and Issuance of Visit Visas and Limited Stay Visas. 
The laws and regulations which are the basis for implementing the temporary residence permit of foreign investors and directors or commissioners of a limited liability company, consist of:

Article 48 Regulation Head of ICB Concerning Guidelines and Procedures for Licensing and Investment Facilities;

Article 10 paragraph (1) of the Regulation Minister of Manpower and Energy of Mineral Resources Concerning Procedures for the Use of Foreign Workers.

As observed, three regulations above are derivatives of the Investment Law, the Immigration Law, the Limited Liability Company Law and the Presidential Regulation on the Use of Foreign Workers.

Gustav Radbruch does not want to confuse sein and sollen in a form of law, what should be and what happens in reality. The law must carry the value of justice that exists in concrete human life. Science must have truth values and good norms. Likewise, knowledge that has these truth values can achieve the ultimate goal of real human needs. So that sein is described as material and sollen is a form of law. Justice can be realized if the material can fill the legal form and the legal form can protect the material. The aspect of justice shows equal rights before the law (Rahardjo, 2013:117). Rules are not only impartial and must be fair, but also must be implemented honestly, in accordance with proper standard procedures and do not care about race, ethnicity, colour or social status. This is also a concept in the Investment Law that does not differentiate the country of origin of investors. Further to this view, it bears to a type of justice called procedural justice (Ali, 2009:185). Justice makes procedure a legal goal. According to John Rawls, the fair way to unite various different interests is through the balance of these interests, without giving special attention to the interests themselves (Ali, 2009:122).

Regulation Head of ICB provides justice both procedurally and substantively. The initial implementation arrangements in submitting ICB recommendations with attachments in the form of share values based on the company's deed of establishment reflect the content of Article 49 Paragraph (3) of the Regulation Head of ICB. Fulfilment of the duties and obligations of an investor as a director is also explicitly stated in the deed of incorporation of the company. The coherence of the Limited Liability Company Law on the company's deed of incorporation and supported by Regulation Head of ICB shows fairness that provides a balance to the position of an investor who is also a director of a company. Likewise, the contents of the Regulation of the Minister of Manpower and Energy and Mineral Resources concerning Procedures for the Use of Foreign Workers, have united different interests between each government agency, in this case the ICB and the Ministry of Manpower. Application for a work permit in the form of EPP is no longer required for an investor who is also a director of the company.

The standard priority teaching in Gustav Radbruch's theory teaches the principle of priority where the first priority is justice (Ali, 2009:231). Thus, the rules and implementation of these rules, which are legal promises, can provide legal certainty to foreign investors so that justice can be realized for foreign investors. Immigration in the Ministerial Regulation does not provide further details if an investor are also a director.

Legal certainty should provide assurance that the law (which contains the norms for advancing goodness) actually functions as a rule that should be obeyed (Rahardjo, 2013). Legal certainty is a legal operational framework. The contents of the Regulation of the Minister of Manpower and Energy and Mineral Resources concerning Procedures for the Use of Foreign Workers have reflected the values of goodness that have been previously regulated by the Presidential Regulation on Foreign Workers. Meanwhile, the regulations governing the granting of a limited stay permit, based on the Ministerial Regulation on Technical Procedures for Application and Granting of Visas and Limited Stay Visas, provide an explanation that is contrary to the contents of the norms which have coherence with these norms. This gives legal uncertainty to investors who are also directors of a limited liability company. Radbruch argues that demands for justice and legal certainty are a permanent part of law (Rahardjo, 2013:188).

Regulation of Ministry of Justice and Human Rights Concerning Technical 
Procedures for Application and Issuance of Visit Visas and Limited Stay Visas a regulation that regulates the procedures for granting a limited stay permit based on the contents of the norms above, namely the Immigration Law and the Investment Law. However, this regulation only regulates the position of an investor, where in reality, there are several limited companies that have directors who are also investors of the same company. Meanwhile, the Regulation of the Minister of Manpower and Energy and Mineral Resources concerning Procedures for the Use of Foreign Workers, formulates the contents of the regulation in more detail and clearly based on the above regulation, namely the Presidential Regulation on Foreign Workers. Regulation of the Minister of Manpower and Energy and Mineral Resources in reality is not supported by the Minister of Immigration in terms of residence permits for foreign investors and company directors. When these two rules are implemented, clash and disagree from one and another. According to Professor Satjipto Rahardjo, legal certainty is only related to the existence of statutory law (Rahardjo, 2013:235).

The Manpower Regulation provides an explanation that a work permit is no longer required if an investor with a certain share value applies for a temporary residence permit in Indonesia. The purpose of this regulation is to provide clarity on the legal rights of investors and company directors. The right which ultimately also gives his obligations as an investor or a director, an obligation for the value of certain shares and an obligation for the running of the company. Requirements that have been written in the Limited Liability Company Law and are also detailed in the company's deed of incorporation are the obligations of an investor who is also a director of a company. Likewise, the obligation for the value of certain shares is the initial condition confirmed by ICB if they want to apply for a residence permit as a director and an investor.

Finality contains elements of relativity, more as an ethical value in law. Finality can come from 3 types of subjects, namely:

Individuals are humans as individuals, and laws are made with the aim of individuality so that individuals or their dignity are not only exalted but also given special protection;

Collectively, that is, if the goal of law is the progress of the state, it will produce a collective legal system and is usually found in many socialist countries and;

Culture, namely the legal system created is a transpersonal legal system, cultural aspects or the results of civilization receive special attention, such as issues concerning democracy, human rights and the environment which are the affairs of all mankind guaranteed by international law (Rahardjo, 2013).

Finality provides fairness, definite values and show virtue for investors and company directors, values which are the ideals of law. Indonesia, which in the preparation of every statutory regulation must be based on the spirit of Pancasila and the 1945 Constitution. The basis and main objective of the formation of the Investment Law is the state's need for development costs by creating a conducive investment climate and having law enforcement for the investors. The main objective of the investment law product is for the interest of Indonesian without distinguishing country of origin of each investor. The Ministerial Regulations for each government agency contain technical rules, requirements and procedures for each institution having special authority. Regulation of Ministry of Justice and Human Rights Concerning Technical Procedures for Application and Issuance of Visit Visas and Limited Stay Visas and Regulation Minister of Manpower and Energy of Mineral Resources Concerning Procedures for the Use of Foreign Workers is ministries that have authority in each of their fields, namely labour and immigration. Although these two ministries are not under same ministry, they do have rules that are interrelated with one another, rules governing the legal standing of an investor (investor) and a director of a company.

Every statutory regulation, both the rules in the Investment Law, the Limited Liability Company Law, the Presidential Regulation and the Ministerial Regulation which regulates the technical procedures of the law above, must have these 3 aspects. Fairness that provides equal rights before the law, finality which shows a mirror of justice and legal certainty that shows legal guarantees and contains positive values in a statutory regulation 
so that all these rules can be obeyed and obeyed (Ansori, 2018:123). Fairness and finality are the ideal framework of legislation, and legal certainty is the legal operational framework. Clashes on Ministerial Regulations which create conflicts shall not produce legal certainty. Investors who are positioned as directors of a foreign investment, in carrying out their duties and responsibilities as directors, will feel uncomfortable and safe. The conflict between fairness and legal certainty or fairness with finality, or if the three aspects are not valid or implemented proportionally, could affect a blurred on legal certainty therefore legal system must be released.

\section{CONCLUSIONS}

Based on the results and discussion explained above, thus it can be concluded that the Regulation of the Minister of Manpower and the Regulation of the Minister of Justice and Human Rights has an equal and balanced position. The two regulations should be a continuation of the technical rules for the Presidential Regulation on the Use of Foreign Workers, the Investment Law and the Limited Liability Company Law, which hierarchically have a position above the two ministerial regulations. In addition, the two Ministerial regulations, which contain technical regulations on a law, should have a relationship and connection with the law above it. Both the Directorate General of Immigration and the Ministry of Manpower are two government agencies which in one of their duties take care of the same field, namely Foreign Citizens. The Ministry of Manpower deals with the field of employment of foreigners, both technical regulations regarding fields of work that are allowed for foreign workers and granting work permits. Meanwhile, the Directorate General of Immigration, under the Ministry of Law and Human Rights, is a state institution that deals with residence permits for foreign nationals (temporary or permanent), either as investors, workers or other visits. Regulation of Ministry of Justice and Human Rights Concerning Technical Procedures for Application and Issuance of Visit Visas and Limited Stay Visas is made in 2016 based on the Immigration Law made in 2011. Meanwhile, Regulation Minister of Manpower and Energy of Mineral Resources Concerning Procedures for the Use of Foreign Workers is made in 2018 which follows Presidential Regulation Concerning Utilization of Foreign Workers made in 2018. Although statutory regulations are not supposed to change constantly, but once there are new rules issued that have coherence with other institutional rules, then it is appropriate that these rules adjust to one another. Based on the legal principle of lex specialist derogate legi lex generalis, the Regulation of the Minister of Manpower and Energy of Mineral Resources is a government agency that has the authority to issue a work permit for a foreign worker, so this rule should also be a reference for the Directorate General of Immigration in terms of technical regulations for granting permits, temporary residence of a foreigner. Likewise, in the legal principle lex posteriori derogate legi priori, namely the new laws and regulations overriding the enactment of the old laws. The old regulations should be updated by considering the newest rules above them. Legislation that is dynamic and comprehensive in nature, following the spirit of any laws above it and other laws that are parallel to it.

Every statutory regulation made must be based on Pancasila and the 1945 Constitution, so as to prioritize the interests of the Indonesian people. Ministerial Regulation on Technical Procedures for Application and Issuance of Visas and Limited Stay Visas, although in their capacity to grant a residence permit it must be based on the interests of the Indonesian people, on the other hand, the requirements for an investor to become a director of a company and be granted a temporary residence permit facility, requires a share value that is not little and other obligations as a director and investor (investor). A rule that contains legal certainty is a characteristic of a responsive rule and contains virtuous values. These values of virtue reflect justice, justice that shows equal rights before the law, rights as a director and rights as an investor in a company. The values of virtue of an investor and company directors will not be a threat to the Indonesian people with the assumption that they can take a portion of jobs for the local community. The government through a Presidential Regulation has limited the business fields that are possible for foreign investors to be able to do business in Indonesia. Investment is expected to help the economy and national development, absorb employment opportunities, transfer technology and expertise from foreign workers to their companions who are Indonesian Workers. Thus, 
finality can be created in accordance with the objectives of the law itself.

Based on the results above, it can be suggested that the Directorate General of Immigration should update the relevant Ministerial Regulations relating to the Presidential Regulation Concerning Utilization of Foreign Workers, considering that the Ministry of Law and Human Rights Regulation was made in 2016 and is not in accordance with the Presidential Regulation made in 2018. Likewise, when considering the hierarchy of statutory regulations, the position of the Ministry of Law and Human Rights Regulation is under the position of a Presidential Regulation. It is understood that the basis of all laws and regulations in Indonesia is based on Pancasila and the 1945 Constitution so that the interests of the Indonesian people are prioritized. The changing times require dynamic and effective laws and regulations. Immigration, which is the spearhead of the entry and exit of foreigners to Indonesia, should be able to provide dynamic rules according to the times, effective and easy to understand so as not to cause ambiguity. Law enforcement is needed to create a conducive investment climate. The implementation of temporary residence permit arrangements owned by the Directorate General of Immigration should provide legal certainty for investors and company directors in Indonesia. However, in order to strengthen supervision in the implementation of arrangements for investors and company directors so as not to do business outside of their own company, more detailed and accurate requirements are needed. For example, the requirements for share value per investor who is a board of directors, are not only provided with proof of shares in the form of a copy of the company's deed of establishment, but also in the form of a copy of bank transactions, either cash deposits/money transfers between banks, or it can also be a statement letter from the bank, that The bank has received a certain investment value of the shares on behalf of the investor and the company directors.

\section{REFERENCES}

Ali, A. (2009). Menguak Teori Hukum (Legal Theory) dan Teori Peradilan (Judicialprudence). Jakarta: Kencana.

Ansori, L. (2018). Pengujian Peraturan Perundang-Undangan. Malang: Setara Press.

Asshiddiqie, J., \& Safa'at, M. A. (2018). Teori Hans Kelsen Tentang Hukum. Jakarta: Konstitusi Press.

Bunawan, P. (2017). Foreign Investment in Indonesia The Legal Aspects under the New Indonesian Investment Law. Dialogia Iuridica: Jurnal Hukum Bisnis Dan Investasi, 8(2), 01. https:// doi.org/10.28932/di.v8i2.719

Fuady, M. (2013). Teori-Teori Besar (Grand Theory) Dalam hukum. Jakarta: Kencana.

Indrati, M. F. (2007). Ilmu Perundang-Undangan Jenis, Fungsi dan Materi Muatan. Jakarta: Kanisius.

Kairupan, D. (2013). Aspek Hukum Penanaman Modal Asing di Indonesia. Jakarta: Kencana Prenada Media Group.

Rahardjo, S. (2013). Teori Hukum. Jogjakarta: Genta Publishing.

Rusdiko, I. M., Widia, I. K., \& Rideng, I. W. (2019). Legal Certainty of Guarantor for the Existence of Foreign Investors in Indonesia. Jurnal Hukum Prasada, 6(2), 123-129. https://doi.org/http:// dx.doi.org/10.22225/jhp.6.2.1086.123-129

Syaifuddin, M. (2012). Hukum Kontrak Memahami Kontrak Dalam Perspektif Filsafat, Teori, Dogmatik dan Praktik Hukum (Seri Pengayaan Hukum Perikatan). Jakarta: Mandar Maju.

Taduri, J. N. A. (2021). The Legal Certainty and Protection of Foreign Investment Againsts Investment Practices in Indonesia. Lex Scientia Law Review, 5(1), 119-138. https:// doi.org/10.15294/lesrev.v5i1.46286

Undang Undang Nomor 25 Tahun 2007 Tentang Penanaman Modal.

Undang Undang Nomor 40 Tahun 2007 Tentang Perseroan Terbatas.

Undang Undang Nomor 6 Tahun 2011 Tentang Keimigrasian.

Undang Undang Nomor 12 Tahun 2011 Tentang Pembentukkan Peraturan Undang-Undang.

Peraturan Presiden Nomor 20 Tahun 2018 Tentang Tenaga Kerja Asing.

Peraturan Menteri Kehakiman dan Hak Asasi Manusia Nomor 51 Tahun 2016 Tentang Perubahan Atas Peraturan Menteri Kehakiman dan Hak Asasi Manusia Nomor 24 Tahun 2016 Tentang Prosedur Teknis Permohonan Dan Pemberi Visa Kunjungan dan Visa Tinggal Terbatas.

Peraturan Menteri Ketenagakerjaan Republik Indonesia Nomor 10 Tahun 2018 Tentang Tenaga 

Investment

Kerja Asing.

Peraturan Kepala Badan Kordinasi dan Penanaman Modal Nomor 6 Tahun 2018 yang telah diubah menjadi Peraturan Kepala Badan Kordinasi dan Penanaman Modal Nomor 5 Tahun 2019 Tentang_Pedoman dan Tata Cara Perizinan dan Fasilitas Penanaman Modal. 